\title{
SEASONAL AND TEMPORAL VARIATION IN SOIL MICROBIAL BIOMASS C, N AND P IN DIFFERENT TYPES LAND USES OF DRY DECIDUOUS FOREST ECOSYSTEM OF UDAIPUR, RAJASTHAN, WESTERN INDIA
}

\author{
PATEL, K. ${ }^{1}$ - NIRMAL KUMAR, J.I. ${ }^{1}{ }^{*}-\mathrm{N}$ KUMAR, R. ${ }^{2}-$ KUMAR BHOI, R. ${ }^{1}$ \\ ${ }^{I}$ P.G. Department of Environmental Science and Technology, \\ Institute of Science and Technology for Advanced Studies and Research (ISTAR), \\ Vallabh Vidyanagar, 388 120, Gujarat, India \\ (phone: +91 09825968242) \\ ${ }^{2}$ Department of Biological and Environmental Science, \\ N.V. Patel college of Pure and Applied Sciences, \\ Vallabh Vidyanagar - 388 120, Gujarat, India \\ e-mail:nvpas2009@gmail.com \\ *Corresponding author \\ e-mail: istares2005@yahoo.com \\ (Received $27^{\text {th }}$ January 2010 ; accepted $28^{\text {th }}$ May 2010)
}

\begin{abstract}
The soil microbial biomass of soil is being increasing recognized as sensitive indicator of soil quality. Its knowledge is fundamental for sustainable environment management. The soil microbial biomass $\mathrm{C}, \mathrm{N}$ and $\mathrm{P}$ were studied in four different land uses of dry tropical forest of Udaipur, Rajasthan, Western India to assess the influence of abiotic, physico-chemical variables and difference in different land uses (mixed forest, butea plantation, grassland and agricultural lands) on the seasonal variation in soil microbial biomass. Microbial biomass $\mathrm{C}, \mathrm{N}$ and $\mathrm{P}$ were highest during rainy season and lowest during winter in all the four different land use with the exception of microbial $\mathrm{N}$ which was lowest in summer in mixed forest and butea plantation. Microbial biomass $\mathrm{C}$ and $\mathrm{N}$ were shown to be significantly correlated to the abiotic and physico-chemical variables of the soil, such as soil temperature, relative humidity, soil moisture, organic $\mathrm{C}$, total $\mathrm{N}$, clay, and $\mathrm{pH}$. Present study clearly shows that land use has a significant effect on microbial biomass $\mathrm{C}, \mathrm{N}$ and $\mathrm{P}$ in soil by altering natural soil characteristics under the same ecological conditions.
\end{abstract}

Keywords: Soil microbial biomass, soil nutrient pool, dry tropical forest, land use type, soil

\section{Introduction}

Soil organic matter is an important components of soil quality and productivity; however, its measurement alone does not adequately reflect change in soil quality and nutrient status (Bezdicek et al., 1996). Measurement of biologically active functions of organic matter, such as microbial biomass $\mathrm{C}, \mathrm{N}, \mathrm{P}$ and potential $\mathrm{C}, \mathrm{N}$ and $\mathrm{P}$ mineralization, could better reflect changes in soil quality and productivity. Soil microbial biomass is an important parameter linking the plants to soil. Soil microbial biomass comprises about 2-3\% of total organic carbon in the soil and has been recognized as an important source of nutrients to plants because of its fast turnover. The soil microbial biomass is the labile pool of organic matter (Jenkinson and Ladd, 1981) and act as both source and sink of plant nutrients (Singh et al. 1989). It plays a crucial role in nutrient cycling and its importance in soil fertility and nutrient concentration is well recognized. Influence of environmental factors to microbial population and 
microbial biomass plays an important role in nutrients cycling in an ecosystem. The cycling of nutrients in soils of forest ecosystems is, to varying degrees, dependent on the energy supply to and through the soil biota.

\section{Review of literature}

The soil microbial biomass is an important labile pool of $\mathrm{C}, \mathrm{N}$, and $\mathrm{P}$ and fluctuations in its size and activity can significantly influence crop productivity (Rosswall and Paustian, 1984; McGill et al., 1986). Soil physico-chemical characteristics also has a great impact on microbial biomass and microbial activity and can be used to measure soil quality (Parr and Papendick, 1997) but it may take years for these parameters to make significant changes in soil. Changes in the microbial population in response to variation in soil conditions (Moisture, Organic $\mathrm{C}$, nutrients, temperature and $\mathrm{pH}$ ) have serious implication for nutrient cycling with microorganisms acting as a source and sink of nutrient. Soil biological and biochemical changes are very sensitive to small changes in soil conditions (degradation, erosion) and thereby give more accurate and immediate information in soil quality because soil microbial activity has a direct influence in ecosystem stability and fertility (Smith and Papendick, 1993). Insam et al. (1989) also proposed that the ratio of microbial biomass to total organic carbon in a soil might serve as a quantitative indicator of carbon dynamics in the soil. Climatic seasonality has been reported to influence microbial population and soil microbial biomass (Schimel et al., 1994) either directly by influencing microbial response to soil changes or in directly by influencing by plant metabolism.

Information on soil microbial biomass in different forest ecosystems have been reported by several workers (Srivastava and Singh, 1991; Billore et al., 1995; Joergensen et al., 1995; Arunachalam et al., 1996; Mendham et al., 2002; Lee and Jose, 2003) but information on seasonal changes in the microbial biomass in an annual cycle in forest ecosystem is limited (Diaz-Ravina et al., 1995; Arunachalam and Arunachalam, 2000). Therefore, the present study was undertaken to evaluate the seasonal fluctuation in the microbial $\mathrm{C}, \mathrm{N}$, and $\mathrm{P}$ and the influence of abiotic, physicchemical variables on the microbial biomass $(\mathrm{C}, \mathrm{N}$, and $\mathrm{P})$ in a dry tropical deciduous forest of Udaipur, Rajasthan, Western India.

\section{Materials and methods}

The study site is located at $23^{\circ} 3^{\prime}-30^{\circ} 12^{\prime} \mathrm{N}$ longitude and $69^{\circ} 30^{\prime}-78^{\circ} 17^{\prime} \mathrm{E}$ latitude in Aravally hills a distance of $70 \mathrm{~km}$ from Udaipur city, Rajasthan at an altitude ranging from 575 to $585 \mathrm{~m}$ above sea level. There are three distinct seasons per year: winter (November to February), summer (April to mid-June), and a rainy season (mid-June to mid- September). The months of October and March are transitional periods and are known as autumn and spring, respectively. The climate of Rajasthan is tropical with a maximum of $46.3{ }^{\circ} \mathrm{C}$ and a minimum of $28.8{ }^{\circ} \mathrm{C}$ temperature during summers. Winters are a little cold with the maximum temperature rising up to $26.8{ }^{\circ} \mathrm{C}$ and the minimum dropping to $2.5^{\circ} \mathrm{C}$. The average annual rainfall of the area is less than $400 \mathrm{~mm}$.

The study was conducted year August 2008 to July 2009. Four experimental different land use types are selected for this study (mixed forest, butea plantation, grassland and agricultural land) which more or less exhibit the same ecological conditions. The elevation of forest land approximately $150 \mathrm{~m}$ and average slope is $55 \%$ and its 
dominated by Tectona grandis, Miliusa tomentosa, Lannea coromondica, Annona squamosa, Anogeissus latifolia, Wrightia tinctoria, Aegle marmelos, Boswellia serrata, Butea monosperma, Holoptelea integrifolia, Sterculia urens, Acacia Senegal. The elevation of butea plantation is approximately $100 \mathrm{~m}$ and slope is $45 \%$ and its dominated by Butea monosperma, Lannea coromondica. The elevation of Grassland and agricultural land is approximately $65 \mathrm{~m}$ and slope is $20 \%$. The major annual crops alternatively cultivated in the agricultural land include Saccharum officinalae, Zea mays, Cicer aurentum.

Soil is alluvial, sandy loam type of present study site. The soil is well drained with yellowish brown to deep medium black in colour. The soil samples were collected from the upper layer of 0-10 $\mathrm{cm}$ in depth from the four different land use types (mixed forest, butea plantation, grassland and agricultural land) for the estimation of microbial biomass. The soil samples were sieved $(<2 \mathrm{~mm})$ to remove stones, coarse and roots and were kept at room temperature for a day. Three replicates were collected every month from each site for the estimation of microbial biomass $(\mathrm{C}, \mathrm{N}$ and $\mathrm{P})$. Microbial biomass (C, N and P) were determined by fumigation extraction method (Anderson and Ingram, 1993). Microbial biomass $C$ was determined by modified Walkley Black method and calculated by using Vance et al. (1987):

$$
\text { microbial } \mathrm{C}=\operatorname{KEC} \times \text { 2:64 }
$$

Microbial biomass $\mathrm{N}$ was determined by microkjeldahl method (Bremner and Mulvaney, 1982) and calculated by Brookes et al. (1985):

$$
\text { microbial } \mathrm{N}=\text { KEN X 1:46 }
$$

and microbial biomass $\mathrm{P}$ was determined by ammonium molybdate stannous chloride method (Sparling et al., 1985) and calculated by Brookes et al. (1982):

$$
\text { microbial } \mathrm{P}=\mathrm{KEP} X \text { 2:5 }
$$

Where, KEC, KEN and KEP are the difference between $\mathrm{C}, \mathrm{N}$ and $\mathrm{P}$ extracted from fumigated and unfumigated soils.

The soil texture was analyzed by pipette method (Gee and Bauder, 1986). Soil moisture by gravimetric method; soil temperature is determined by a soil thermometer. Soil $\mathrm{pH}$ is determined (1:5 water suspension) by $\mathrm{pH}$ meter (Systronics). The bulk density of soil $\left(\mathrm{g} \mathrm{cm}^{3}\right)$ was calculated using mass and volume. Pore space was calculated using the bulk and particle density. Soil organic $\mathrm{C}$, total $\mathrm{N}$ and total $\mathrm{P}$ were estimated by the methods given by (Anderson and Ingram, 1993; Bremner and Mulvaney, 1982; Sparling et al., 1985), respectively.

Student's t-test and ANOVA are used to statistically analysed the data.

\section{Results}

\section{Soil characteristics}

The soil was sandy loamy with $50.02-56.54 \%$ sand $12.7-19.4 \%$ clay and $28.9-$ $32.5 \%$ silt in all the types of land use. Soil moisture ranged from 24.17 to $29.74 \%$, soil temperature ranged from 16.9 to $19.1{ }^{\circ} \mathrm{C}$, soil $\mathrm{pH} 5.6-6.9$, soil organic carbon $2.24-$ $4.53 \%$, soil total N $0.32-0.57 \%$, total P $0.041-0.072 \%$ and bulk density $0.86-1.23$ 
$\mathrm{g} \mathrm{cm}^{3}, \mathrm{C} / \mathrm{N}$ ratio varied from 6.5 to 8.5 across the four different types of land use (Table 1).

Table 1. Abiotic variables and physico-chemical characteristics of soils in different land uses.

\begin{tabular}{lcccc}
\hline & Mixed Forest & $\begin{array}{c}\text { Butea } \\
\text { Plantation }\end{array}$ & Grassland & $\begin{array}{c}\text { Agricultural } \\
\text { land }\end{array}$ \\
\hline Abiotic variables & & & & \\
Soil temperature $\left({ }^{\circ} \mathrm{C}\right)$ & 18.7 & 19.1 & 18.4 & 16.9 \\
Soil moisture $(\%)$ & 25.28 & 24.17 & 25.76 & 29.74 \\
Relative humidity $(\%)$ & 53.49 & 53.49 & 53.49 & 53.49 \\
Mean air temperature $\left({ }^{\circ} \mathrm{C}\right)$ & 24.83 & 24.83 & 24.83 & 24.83 \\
Rainfall (mm) & 130.2 & 130.2 & 130.2 & 130.2 \\
Soil physico-chemical variables & & & & \\
Texture & & & & \\
$\quad$ Sand $(\%)$ & 53.8 & 56.54 & 55.71 & 50.02 \\
$\quad$ Silt $(\%)$ & 32.55 & 30.74 & 28.84 & 30.6 \\
$\quad$ Clay $(\%)$ & 13.65 & 12.72 & 15.45 & 19.38 \\
Bulk density $\left(\mathrm{g} \mathrm{cm}{ }^{3}\right)$ & $0.86 \pm 0.23$ & $0.88 \pm 0.253$ & $1.02 \pm 0.13$ & $1.23 \pm 0.217$ \\
Pore Space $(\%)$ & 67.67 & 66.84 & 61.51 & 53.63 \\
Soil pH & $5.2-5.7$ & $5.5-6.1$ & $6.0-7.3$ & $6.9-7.8$ \\
Soil organic C $(\%)$ & $2.36-4.28$ & $2.24-3.78$ & $1.81-3.42$ & $1.35-2.53$ \\
Soil total N $(\%)$ & $0.36-0.52$ & $0.32-0.49$ & $0.25-0.41$ & $0.29-0.47$ \\
Soil available P $(\%)$ & $0.047-0.064$ & $0.041-0.059$ & $0.035-0.042$ & $0.031-0.052$ \\
C:N & $6.5-8.2$ & $7.0-8.5$ & $6.6-8.6$ & $7.0-7.9$ \\
\hline
\end{tabular}

\section{Microbial $C, N$ and $P$}

In mixed forest, the microbial $\mathrm{C}, \mathrm{N}$ and $\mathrm{P}$ ranged from 94.2 to $1507.8 \mu \mathrm{g} \mathrm{g}^{-1}, 78.2$ to $128.3 \mu \mathrm{g} \mathrm{g}^{-1}$ and 39.7 to $84.4 \mu \mathrm{g} \mathrm{g}^{-1}$ respectively (Fig 1 ).

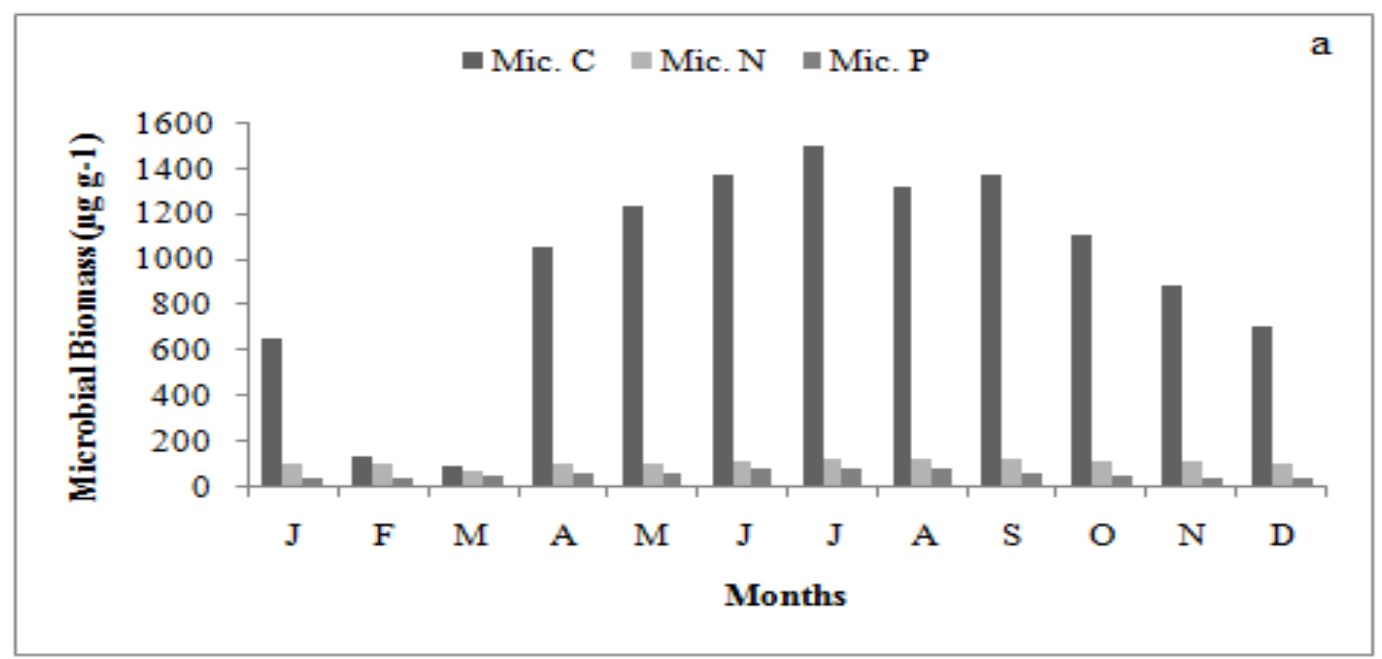

Figure 1. Monthly variation of microbial biomass $C, N$ and $P$ in mixed forest 
In butea plantation, the value of microbial biomass $\mathrm{C}, \mathrm{N}$ and $\mathrm{P}$ varied from 184.5 to $1387.7 \mu \mathrm{g} \mathrm{g}^{-1}, 69.8$ to $114.2 \mu \mathrm{g} \mathrm{g}^{-1}$ and 32.7 to $80.1 \mu \mathrm{g} \mathrm{g}^{-1}$ respectively (Fig 2).

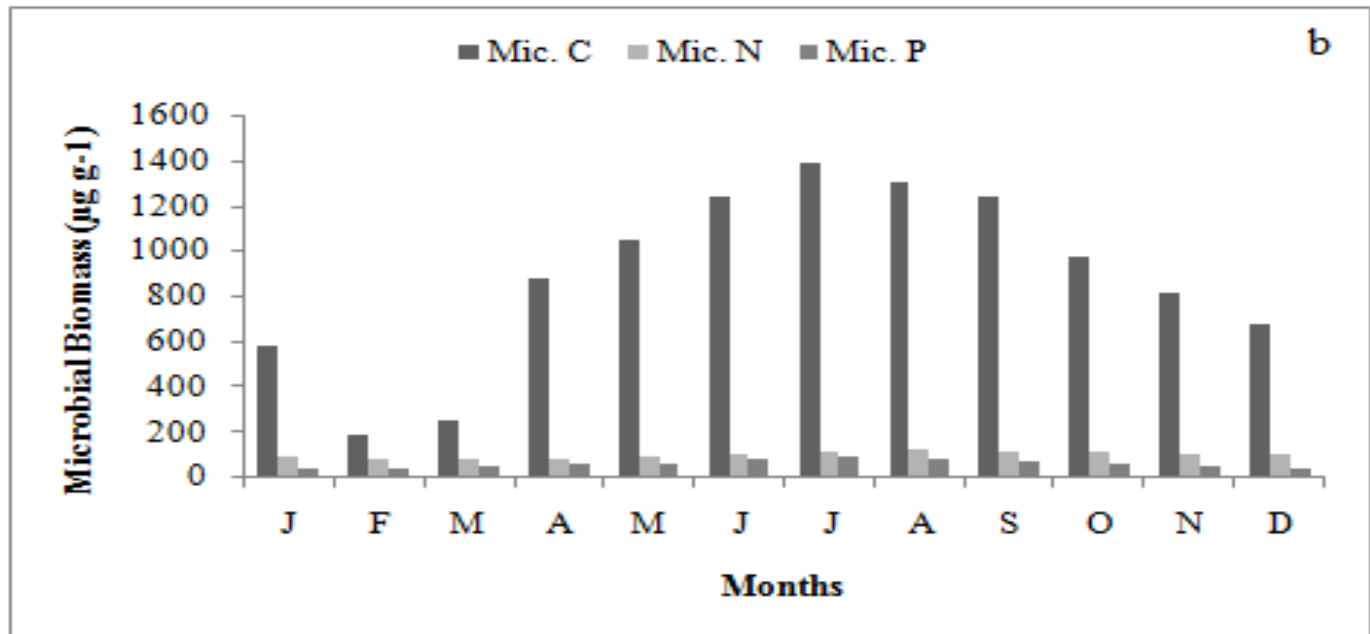

Figure 2. Monthly variation of microbial biomass $C, N$ and $P$ in butea plantation

In grassland, the val. of microbial $\mathrm{C}, \mathrm{N}$ and $\mathrm{P}$ was ranged from 119.1 to $435.7 \mu \mathrm{g} \mathrm{g}^{-1}$, 28.5 to $56.3 \mu \mathrm{g} \mathrm{g}^{-1}$ and 13.4 to $26.7 \mu \mathrm{g} \mathrm{g}^{-1}$ respectively (Fig 3).

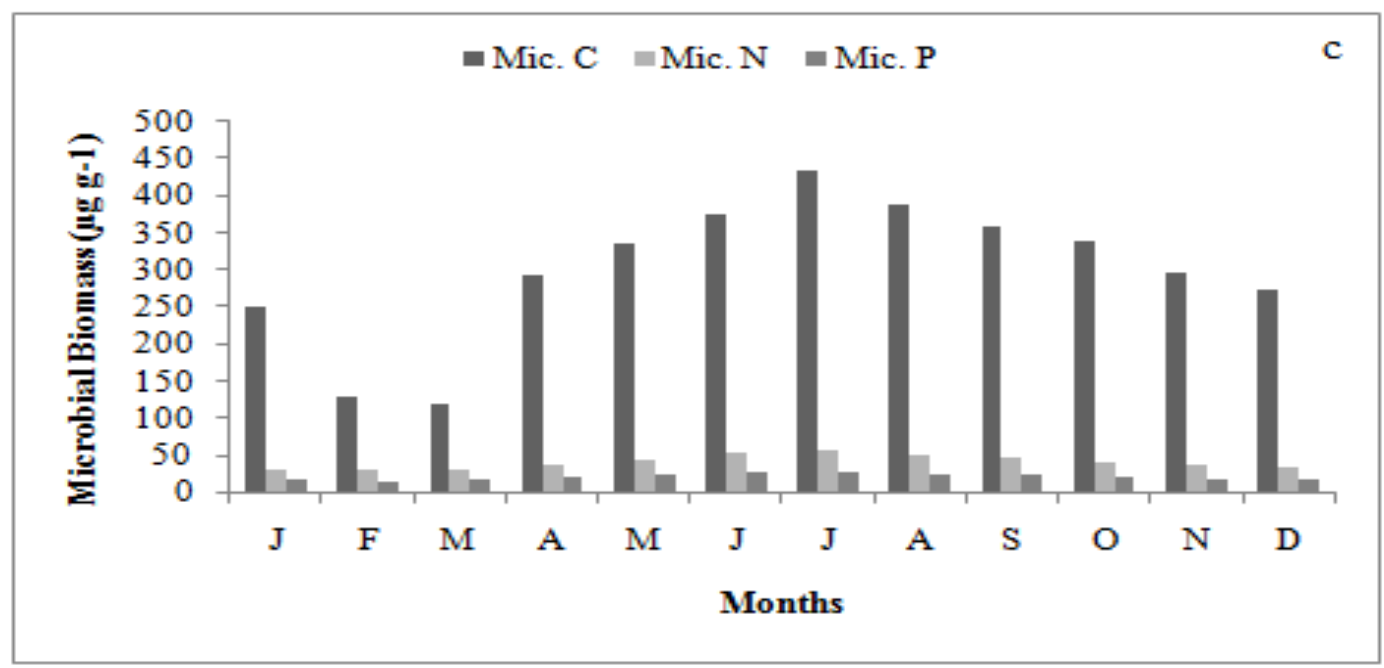

Figure 3. Monthly variation of microbial biomass $C, N$ and $P$ in grassland

In agricultural land, the microbial biomass $\mathrm{C}, \mathrm{N}$ and $\mathrm{P}$ varied from 89.6 to $335.7 \mu \mathrm{g}$ $\mathrm{g}^{-1}, 23.8$ to $51.4 \mu \mathrm{g} \mathrm{g}^{-1}$ and 11.9 t0 $24.9 \mu \mathrm{g} \mathrm{g}^{-1}$ respectively (Fig 4). The maximum value of microbial $\mathrm{C}, \mathrm{N}$ and $\mathrm{P}$ was obtained in the month of July and the minimum in the month of March (Fig. 1). Seasonally, however, the microbial C, N and $\mathrm{P}$ value was recorded to be maximum during the rainy season and minimum during winter in all the types of land use with the exception of microbial $\mathrm{N}$ which was minimum in summer in mixed forest and butea forest. However, microbial $\mathrm{C}, \mathrm{N}$ and $\mathrm{P}$ values are significantly higher in mixed forest than that of butea plantation, grassland, agriculture land $(\mathrm{P}<$ 0.01 ) (Table 2). 


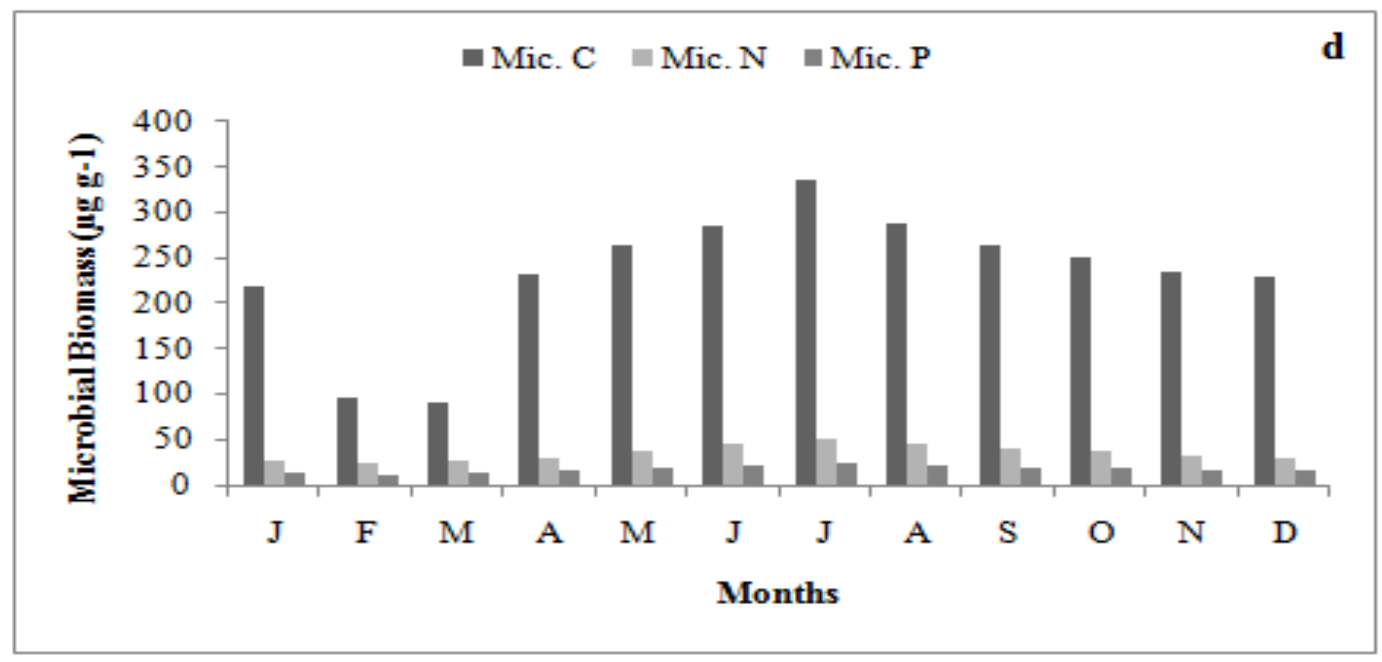

Figure 4. Monthly variation of microbial biomass $C, N$ and $P$ in agricultural land

\section{Contribution of microbial biomass to the soil nutrient pool}

In mixed forest, microbial $C$ contributed $1.50-4.22 \%$ of the total soil organic $C$, the maximum being contributed during rainy season and the minimum during winter season. The percentage contribution of microbial biomass $\mathrm{N}$ and $\mathrm{P}$ to total $\mathrm{N}$ and total $\mathrm{P}$ ranged from 2.06 to $3.52 \%$ and 6.78 to $14.91 \%$ respectively. Maximum microbial biomass $\mathrm{N}$ and $\mathrm{P}$ was contributed during rainy season and minimum during winter season. In butea plantation, the contribution of microbial biomass $\mathrm{C}$ to total organic $\mathrm{C}$ was 1.34-4.02 \%, maximum value was recorded during rainy season and minimum during winter season. The percentage contribution of microbial biomass $\mathrm{N}$ and $\mathrm{P}$ to total $\mathrm{N}$ and total available $\mathrm{P}$ was 1.80-3.27 and 6.03-15.61, respectively. Maximum contribution of microbial $\mathrm{N}$ and $\mathrm{P}$ was attained during rainy and summer seasons and minimum was contributed during winter seasons, respectively.

In grassland and agriculture land, contribution of microbial biomass $\mathrm{C}$ to total organic C was 0.54 to $1.18 \%$ and 0.44 to $0.86 \%$ respectively, maximum value was reported during rainy season and minimum during winter season. The contribution microbial $\mathrm{N}$ and $\mathrm{P}$ to total $\mathrm{N}$ and total available $\mathrm{P}$ was $0.63-1.37$ and $2.46-5.20 \%$ in grassland and in agriculture land $3.48-6.10$ and $1.99-4.04 \%$. The microbial C:N and C:P ratios varied from 6.0 to 11.34 and 12.1 to 18.97 across four different types of land use.

The analysis of variance (ANOVA) indicated a significant difference in microbial biomass $\mathrm{C}$ between the different sampling months of summer $(P<0.05)$, rainy $(P<$ $0.05)$, winter $(P<0.05)$ and annually $(P<0.05)$ and significant difference in microbial biomass $\mathrm{N}$ and $\mathrm{P}$ between the different sampling months of summer $(P<0.001)$, rainy $(P<0.001)$, winter $(P<0.001)$ and annually $(P<0.001)$.

Correlation coefficient between $\mathrm{C}_{\text {mic }}, \mathrm{N}_{\text {mic }}, \mathrm{P}_{\text {mic }}$, soil temperature, soil moisture, Relative humidity, mean air temperature, rainfall, clay, Bulk density, pore space, $\mathrm{pH}$, organic $\mathrm{C}$, total $\mathrm{N}$, available $\mathrm{P}$ and $\mathrm{C}: \mathrm{N}$ were calculated (Table 3). The highest positive correlations were between $\mathrm{C}_{\text {mic }}$ and $\mathrm{N}_{\text {mic }}, \mathrm{C}_{\text {mic }}$ and $\mathrm{P}_{\text {mic }}, \mathrm{N}_{\text {mic }}$ and $\mathrm{P}_{\text {mic }}$, relative humidity and microbial $\mathrm{C}, \mathrm{N}$ and $\mathrm{P}$, Soil temperature and microbial $\mathrm{C}, \mathrm{N}$ and $\mathrm{P}$, Soil moisture and microbial $\mathrm{C}, \mathrm{N}$ and $\mathrm{P} ; \mathrm{C}_{\mathrm{mic}}$ and organic $\mathrm{C} ; \mathrm{N}_{\text {mic }}$ and organic $\mathrm{C} ; \mathrm{C}_{\mathrm{mic}}$ and total $\mathrm{N}$; Organic 
$\mathrm{C}$ and total $\mathrm{N}$. On the other hand, the lowest negative correlations between organic $\mathrm{C}$ and $\mathrm{pH}, \mathrm{C}_{\mathrm{mic}}$ and clay, organic $\mathrm{C}$ and clay, bulk density and pore space (Table 3).

Table 2. Microbial C, $N$ and $P\left(\mu g g^{-1}\right)$ in the soils of Mixed forest, Butea forest, Grass land and Agricultural land of Udaipur forest

\begin{tabular}{|c|c|c|c|c|}
\hline & Mixed Forest & $\begin{array}{c}\text { Butea } \\
\text { Plantation }\end{array}$ & Grassland & $\begin{array}{c}\text { Agricultural } \\
\text { land }\end{array}$ \\
\hline \multicolumn{5}{|l|}{ Microbial C } \\
\hline Summer & $971.43^{*}$ & $851.35^{*}$ & $280.53^{*}$ & $218.15^{*}$ \\
\hline Rainy & $1330.00^{*}$ & $1222.98^{*}$ & $380.33 *$ & $284.30 *$ \\
\hline Winter & $643.91 *$ & $560.58 *$ & $236.30 *$ & $194.30 *$ \\
\hline Annual Mean & $981.78 \pm 198.1$ & $878.30 \pm 191.7$ & $299.05 \pm 42.6$ & $232.25 \pm 26.9$ \\
\hline \multicolumn{5}{|l|}{ Microbial N } \\
\hline Summer & $106.00 * * *$ & $83.78 * * *$ & $40.78 * * *$ & $34.55 * * *$ \\
\hline Rainy & $123.30^{* * *}$ & $107.85^{* * *}$ & $47.85^{* * *}$ & $42.83 * * *$ \\
\hline Winter & $107.33^{* * *}$ & $87.98 * * *$ & $32.10 * * *$ & $27.63 * * *$ \\
\hline Annual Mean & $112.21 \pm 5.56$ & $93.20 \pm 7.42$ & $40.24 \pm 4.55$ & $35.00 \pm 4.39$ \\
\hline \multicolumn{5}{|l|}{ Microbial P } \\
\hline Summer & $64.55 * * *$ & $58.23 * * *$ & $21.13 * * *$ & $18.00 * * *$ \\
\hline Rainy & $70.10 * * *$ & $65.58 * * *$ & $23.40 * * *$ & $21.40 * * *$ \\
\hline Winter & $43.38 * * *$ & $35.55 * * *$ & $15.28 * * *$ & $14.35^{* * *}$ \\
\hline Annual Mean & $59.34 \pm 8.14$ & $53.12 \pm 9.04$ & $19.93 \pm 2.42$ & $17.92 \pm 2.03$ \\
\hline \multicolumn{5}{|c|}{ Microbial C:N } \\
\hline Summer & 9.16 & 10.16 & 6.88 & 6.31 \\
\hline Rainy & 10.79 & 11.34 & 7.95 & 6.64 \\
\hline Winter & 6.00 & 6.37 & 7.36 & 7.03 \\
\hline Annual Mean & 8.75 & 9.42 & 7.43 & 6.64 \\
\hline \multicolumn{5}{|c|}{ Microbial C:P } \\
\hline Summer & 15.05 & 14.62 & 13.28 & 12.12 \\
\hline Rainy & 18.97 & 18.65 & 16.25 & 13.29 \\
\hline Winter & 14.85 & 15.77 & 15.47 & 13.54 \\
\hline Annual Mean & 16.54 & 16.54 & 15.00 & 12.96 \\
\hline \multicolumn{5}{|c|}{ Microbial C/Organic C (\%) } \\
\hline Summer & 2.58 & 2.31 & 0.72 & 0.53 \\
\hline Rainy & 4.22 & 4.02 & 1.18 & 0.86 \\
\hline Winter & 1.50 & 1.34 & 0.54 & 0.44 \\
\hline \multicolumn{5}{|c|}{ Microbial N/total N (\%) } \\
\hline Summer & 2.26 & 1.90 & 0.89 & 4.72 \\
\hline Rainy & 3.52 & 3.27 & 1.37 & 6.10 \\
\hline Winter & 2.06 & 1.80 & 0.63 & 3.48 \\
\hline \multicolumn{5}{|c|}{ Microbial P/ total P (\%) } \\
\hline Summer & 11.53 & 11.42 & 3.99 & 2.90 \\
\hline Rainy & 14.91 & 15.61 & 5.20 & 4.04 \\
\hline Winter & 6.78 & 6.03 & 2.46 & 1.99 \\
\hline
\end{tabular}

$* \mathrm{P}<0.05, * * * \mathrm{P}<0.001$ 
Table 3. Correlation matrix (r-value) for abiotic, physical, chemical and microbiological characteristic of soil in different land uses

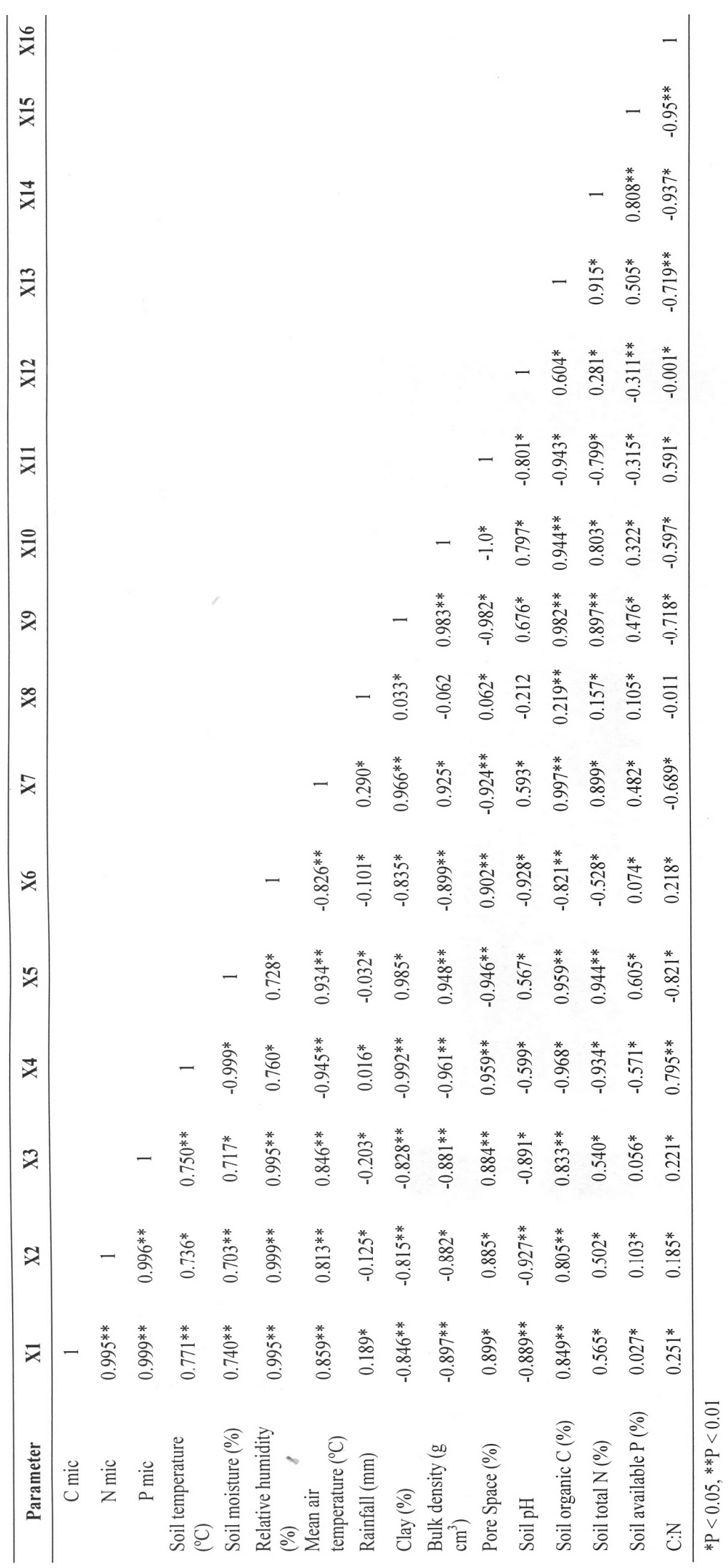




\section{Discussion}

The microbial $\mathrm{C}, \mathrm{N}$ and $\mathrm{P}$ was significantly higher during the rainy season $(\mathrm{P}<0.05$, $\mathrm{P}<0.01)$ and lower in winter season in both the stands with the exception of microbial $\mathrm{N}$ exhibiting lowest value in summer season (Table 2). This may be due to higher immobilization of nutrients by the microbes from the decomposing litters as decomposition rate of litters and microbial activities are at peak during this period. Further, the growth of fungi also increased during this season due to high relative humidity and thus contributing to the soil microbial biomass (Acea and Carballas, 1990).

The seasonal variation of microbial biomass $\mathrm{C}, \mathrm{N}$ and $\mathrm{P}$ values was significant between summer-rainy $(\mathrm{P}<0.01)$ and winter-rainy $(\mathrm{P}<0.01)$; however, there is no significant seasonal variation between summer and winter season which may be due to unexpected rains in winter during the study period thereby increasing the microbial biomass during this season (Fig. 3). However, in tropical dry deciduous forest, savanna and temperate pastures peak values were recorded during early spring or summer (Saratchandra et al., 1984; Singh et al., 1989) and that of subtropical humid forest where maximum value was obtained in winter season (Arunachalam and Arunachalam, 2000) may be due to the differences in quality of litter and rainfall pattern. However, low value of microbial $\mathrm{C}, \mathrm{N}$ and $\mathrm{P}$ in winter season may be due to low activities of microorganisms and slow rate of decomposition of litter in dry and cool period. DiazRavina et al. (1995) reported that lack of water seemed to limit the microbial biomass more than temperature since lower microbial biomass contents were observed in dry period than in wet period. Several studies on soil microbial biomass reported a close relationship between soil moisture and microbial biomass (Acea and Carballas, 1990; Diaz-Ravina et al., 1995) where maximum value of microbial biomass is obtained in wet period and minimum in dry period which are in conformity with our report. Similar observations have been reported by Santruckova (1992) and Lynch and Panting (1982) in different ecosystems (forest, grassland and arable soils of Greece) and arable soil of Oxford shire, UK. The microbial $\mathrm{C}$ value obtained in the present study falls well within the ranges (61-2000 mg g_1) reported by Vance et al. (1987) and Henrot and Robertson (1994) for various temperate and tropical forest soils and of sub-tropical forest (978$2088 \mathrm{mg}$ g_1) reported by Arunachalam and Arunachalam (2000). The microbial N value is comparable to soils of coniferous forest soils (52-125 mg g_1) reported by Martikainen and Palojarvi (1990) and evergreen forests, (42-242 mg g_1) reported by Diaz-Ravina et al. (1988), but lower than that of broad leaved deciduous forest soils (132-240 mg g_1; Diaz- Ravina et al., 1988). The microbial $P$ value falls well within the reported range of 5.3-67.2 $\mathrm{mg}$ g_1 for arable land, grassland and woodland soils (Brookes et al., 1984) and 14-46 mg g_1 for sub-tropical moist forest reported by Arunachalam and Arunachalam (2000). Wardle (1998) reported in his reviewed article on soil microbial biomass dynamics that there is no consistent seasonally determined temporal patterns of microbial biomass change in tropical and warm temperate ecosystems. However, the present study in subtropical forest is contrary to his reports. The value of microbial $\mathrm{C}, \mathrm{N}$ and $\mathrm{P}$ is comparatively higher in forest stand I situated at the foothill than in mixed forest located at higher elevation, which may be due to high soil moisture content and less exposure to sunlight and better quality of litter in former stand favouring the growth of microbes. Besides this amount of litterfall returned on the forest floor was higher than that of plantation, grassland and agriculture land. Thus, the contribution of microbial $\mathrm{C}, \mathrm{N}$ and $\mathrm{P}$ to total soil organic $\mathrm{C}$, total $\mathrm{N}$ and $\mathrm{P}$ was higher in 
forest mixed forest than that of plantation, grassland and agriculture land indicating microbial biomass/nutrients $(\mathrm{C}, \mathrm{N}$ and $\mathrm{P})$ immobilized more in mixed forest.

Both mixed forest and Butea plantation soils have significantly greater organic content and total $\mathrm{N}$ content in the study area when compared with grassland and agriculture land (Table 1). In support this finding, the highest microbial biomass $\mathrm{C}$ and $\mathrm{N}$ value were found in forest soils with highest organic $\mathrm{C}$ and $\mathrm{N}$ content. It is well known that soil organic $\mathrm{C}$ strongly affects the amount and activity of soil microbial biomass (Diaz-Ravina et al, 1988).

The positive and significant relation between the $\mathrm{C}_{\text {mic }}$ and $\mathrm{N}_{\text {mic }}, \mathrm{C}_{\mathrm{mic}}$ and $\mathrm{P}_{\text {mic }}, \mathrm{N}_{\text {mic }}$ and $\mathrm{P}_{\text {mic }}$, relative humidity and microbial $\mathrm{C}, \mathrm{N}$ and $\mathrm{P}$, Soil temperature and microbial $\mathrm{C}$, $\mathrm{N}$ and $\mathrm{P}$, Soil moisture and microbial $\mathrm{C}, \mathrm{N}$ and $\mathrm{P} ; \mathrm{C}_{\mathrm{mic}}$ and organic $\mathrm{C} ; \mathrm{N}_{\text {mic }}$ and organic $\mathrm{C}$ and $\mathrm{C}_{\text {mic }}$ and total $\mathrm{N}$ (Table 3). Our results are consistent with previously reported studies (Arunachalam and Arunachalam, 2000; Sharma etal., 2004; Wright et al., 2005). The relatively dense structure of plants and a greater accumulation of litter and fine roots in the understorey of forest and plantation may favor the growth of microbial populations and the accumulation of $\mathrm{C}$ in microbial biomass.

In this study, there is a significant positive relationship between soil organic $\mathrm{C}$ and total $\mathrm{N}$, organic $\mathrm{C}$ and total $\mathrm{P}$ and total $\mathrm{N}$ and total $\mathrm{P}$ (Table 3). Similarly, previous studies state that if soil organic $\mathrm{C}$ increases, the total $\mathrm{N}$ increase (Manu et al., 1991; Li et al., 2007). The dynamics of $\mathrm{N}$ in mineral soil is closely linked to $\mathrm{C}$, because most $\mathrm{N}$ exists in organic compounds and heterotrophic microbial biomass, which utilize organic $\mathrm{C}$ for energy. As a result, the microbial biomass $\mathrm{N}$ showed a significant positive correlation with microbial biomass $\mathrm{C}$ (Table 3). The result coincides with previous studies (Klose and Tabatabai, 1999; Arunachalam and Arunachalam, 2000; Arunachalam and Arunachalam, 2002; Sharma et al., 2004; Wright et al., 2005).

The $\mathrm{pH}$ of soils in, grassland and agricultural land were moderately acidic ( $\mathrm{pH} 5.65)$ in mixed forest and butea plantation, lightly acidic $(\mathrm{pH} 6.65)$ in grassland and lightly alkaline ( $\mathrm{pH} 7.35)$ in agricultural land. Relatively high values of microbial biomass $\mathrm{C}$, $\mathrm{N}$ and $\mathrm{P}$ in the forest and plantation soils, compared to grassland and agricultural soil, was likely due to $\mathrm{pH}$, because it showed a negative correlation with microbial biomass $\mathrm{C}$ and microbial biomass $\mathrm{N}$ (Table 3). The results of this study reveal that distinct plant community composition associated with 4 land use types, reflecting changes in soil $\mathrm{pH}$ and microbial biomass. Previous work has shown variability in microbial biomass that can be caused by alterations in soil pH (Wardle, 1992). Some authors suggest that maximum activities of soil microbial biomass occur at $\mathrm{pH}$ values of about 6.5 (AcostaMartinez and Tabatabai, 2000).

The clay content of soil is known to play a role in the determining microbial biomass and activity as well as influencing the composition of microbial community (McCulley and Burke 2004). Soils with high clay content lead to more stabilization of soil organic $\mathrm{C}$ and higher microbial biomass (Schimel et al., 1994). In contrast, our results indicate that Cmic $(r=-0.846, \mathrm{P}<0.01)$ and Nmic $(\mathrm{r}=-0.815, \mathrm{P}<0.01)$ were negatively correlated with clay content of soils. Most likely this is due to the variability in the controlling factors of microbial biomass, such as soil organic matter, management practices, and plant species composition, that may have masked the impact of clay content on soil microbial biomass.

The large variation of microbial C:N ratio $(6.0-11.34)$ (Table 2$)$ in the present study areas may be due to low availability of total soil $\mathrm{N}$, however, the present value is close to the range reported by Martikainen and Palojarvi (1990) for various forest soils (6-9) 
and by Fenn et al. (1993) for chaparral soils (7-13). According to Jenkinson and Ladd (1981) C:N ratio of fungal hyphae is often 10-12 and that of bacteria usually between 3 - 5. Since $C: N$ ratio in the present study areas are more than 5, it may be dominated by fungal community. However, several workers have reported that dominance of fungi in an acid forest soil have a significant impact on microbial C:N ratio (Swift et al., 1979; Fliessbach and Reber, 1991). The microbial C:P in the present study falls well within the reported range of 10.6-35.9 by Brookes et al. (1984), but lower than that of dry tropical deciduous forest (35.51) reported by Devi Sarjubala (2002) and sub-tropical humid forest (33.2-98.5) reported by Arunachalam and Arunachalam (2000) which may be due to high microbial biomass $\mathrm{P}$ in the present forest.

The contribution of microbial biomass $C$ to soil organic $C(0.44-4.22 \%)$ and microbial $\mathrm{N}$ to total $\mathrm{N}(0.48-3.52 \%)$ across the four sites varies from season to season attaining highest value in rainy season and low during winter season thereby indicating high immobilization of microbial $\mathrm{C}$ and $\mathrm{N}$ during the rainy season. The present value of microbial $\mathrm{C}$ to organic $\mathrm{C}$ falls within the reported range of tropical forests $(1.5-5.3 \%$; Theng et al., 1989; Luizzao et al., 1992) and temperate forests (1.8-2.9\%; Vance et al., 1987). However, the contribution of microbial biomass $\mathrm{N}$ to total $\mathrm{N}$ is comparable the values reported from agricultural soils (2-6\%; Brookes et al., 1985), acid organic soils (2.8-9.8\%; Williams and Sparling, 1984) and forest soils (3.4- 5.9\%; Martikainen and Palojarvi, 1990). Contribution of microbial P to total Phosphorus $(2.46-5.20 \%)$ across the sites indicates higher immobilization and is comparable to the values reported by Brookes et al. (1984) from deciduous woodland (4.7\%), grasslands (2-4.3\%) and arable land (1.4-3.5\%) and it falls well within the reported range of Yadava and Devi (2004) from semi evergreen forest $(2.74 \%)$ but lower than that of sub-tropical humid forest of North-east India reported by Arunachalam and Arunachalam (2000) owing to high microbial $\mathrm{P}$ and low $\mathrm{pH}$ in those forests.

\section{Conclusion}

Thus, it may be concluded that the soil microbial biomass exhibits strong seasonality and is highly influenced by the abiotic variables. However, soil moisture has a strong influence on the microbial biomass. The microbial $\mathrm{C}: \mathrm{N}$ ratio indicates that soil fertility is influenced by the species composition of the forest. High microbial $\mathrm{N}$ during the rainy season may be onsidered as a nutrient conservation strategy. Further, the proportion of microbial $\mathrm{C}$ and $\mathrm{N}$ to soil $\mathrm{C}$ and $\mathrm{N}$ indicates that $\mathrm{C}, \mathrm{N}$ and $\mathrm{P}$ are immobilized more during rainy season. Results from the present study demonstrate that management practices and certain types of vegetation exert a profound influence on microbial biomass $\mathrm{C}$ and $\mathrm{N}$. Different plant species affect soil microbial processes, which are dependent upon their litter quality and quantity and also upon below-ground biomass supporting microbial activities. The substrate and nutrient limitation of microbial biomass and their central role in the soil nutrient cycling facilitate the use of microbial biomass as an indicator for soil health of land use types. Our data suggest that forest soil may be healthier when compared to other land use soils. In other words, the soil health of land use types is in the order of forest, plantation, grassland and agriculture soil. 
Acknowledgements. Authors are grateful to Mr. Jagadeesh Rao, Executive Director; Mr. Subrat, Mr. Mayank Trivedi, Scientific Officer, Foundation for Ecological Security, Anand, Gujarat for financial assistance of this research project.

\section{REFERENCES}

[1] Acea, M.J., Carballas, T. (1990): Principal components analysis of the soil microbial populations of humid zone of Galicia (Spain). - Soil Biol. Biochem. 22: 749-759.

[2] Acosta-Martinez, V., Tabatabai, M.A. (2000): Enzyme activities in a limed agricultural soil. - Biol. Fertil. Soils. 31: 85-91.

[3] Anderson, J.A., Ingram, J.S.I. (1993): Tropical soil biology and fertility. - In: A Handbook of Methods, CAB. International, Wallingford, Oxon, UK.

[4] Arunachalam, A., Arunachalam, K. (2002): Evaluation of bamboos in eco-restoration of ‘jhum' fallows in Arunachal Pradesh: ground vegetation, soil and microbial biomass. Forest Ecol. Manag. 159: 231-239.

[5] Arunachalam, A., Arunachalam, K. (2000): Influence of gap size and soil properties on microbial biomass in a subtropical humid forest of North-east India. - Plant Soil 223: 185-193.

[6] Arunachalam, A., Maithani, K., Pandey, H.N., Tripathi, R.S. (1996): The impact of disturbance on detrital dynamics and soil microbial biomass of Pinus kesiya forest in North east India. - Forest Ecol. Manage. 88: 273-282.

[7] Billore, S.K., Ohsawa, M., Numata, M., Okano, S. (1995): Microbial biomass Nitrogen pools in soils from a warm temperate grassland and from deciduous and evergreen forests in Chiba, Central Japan. - Biol. Fertil. Soils 19: 124-128.

[8] Bremner, J.M., Mulvaney, C.S. (1982): Nitrogen total. - In: Page, A.L., Miller, R.H., Keeney, D.R. (eds.), Methods of Soil Analysis, American Society of Agronomy and Soil Science Society of America, Madison, WI, pp. 595-624.

[9] Brookes, P.C., Kragt, J.F., Powlson, D.S., Jenkinson, D.S. (1985): Chloroform fumigation and release of soil nitrogen: the effect of fumigation time and temperature. Soil Biol. Biochem. 17: 831-835.

[10] Brookes, P.C., Powlson, D.S., Jenkinson, D.S. (1982): Phosphorus in soil microbial biomass. - Soil Biol. Biochem. 14: 319-329.

[11] Brookes, P.C., Powlson, D.S., Jenkinson, D.S. (1984): Phosphorus in the soil microbial biomass. - Soil Biol. Biochem. 16: 169-175.

[12] Devi Sarjubala, A. (2002): Litter decomposition and nutrient mineralization in the dry tropical deciduous forest ecosystem of Manipur. - Ph.D. Thesis. Manipur University.

[13] Diaz-Ravina, M., Acea, M.J., Carballas, T. (1995): Seasonal changes in microbial biomass and nutrient flush in forest soils. - Biol. Fertil. Soils 19: 220-226.

[14] Diaz-Ravina, M., Carballas, T., Acea, M.J. (1988): Microbial biomass and metabolic activity in four acid soils. - Soil Biol. Biochem. 20: 817-823.

[15] Fenn, M.E., Poth, M.A., Dunn, P.H., Barro, S.C. (1993): Microbial N and biomass respiration and $\mathrm{N}$ mineralization in soil beneath two chaparral species along a fireinduced age gradient. - Soil Biol. Biochem. 25: 457-466.

[16] Fliessbach, A., Reber, H. (1991): Auswirkungen einer langjahrigen zufuhr von klarschlamm auf Bodenmikroorganismen and chre Leistungen Ber Okdog Forschung (Juttch) 6: 327-358.

[17] Henrot, J., Robertson, G.P. (1994): Vegetation removal in two soils of the humid tropics: effect on microbial biomass. - Soil Biol. Biochem. 26:111-116.

[18] Insam, H., Parkinson, D., Domsch, K.H. (1989): Influence of macroclimate on soil microbial biomass. - Soil Biol. Biochem. 21: 211-221.

[19] J.M., Uehara, G. (eds.), Dynamics of Soil Organic Matter in Tropical Ecosystems. University of Hawaii Press, Honolulu, pp. 5-32. 
[20] Jenkinson, D.S., Ladd, J.N. (1981): Microbial biomass in soil: measurement and turnover. - In: Powl, E.A., Ladd, J.N. (eds.), Soil Biochemistry, vol. 5. Dekker, New York, pp. 415-471.

[21] Joergensen, R.G., Anderson, T.H., Wolters, V. (1995): Carbon and nitrogen relationships in the microbial biomass of soils in beech (Fagus sylvatica L.) forests. - Biol. Fertil. Soils 19:141-147.

[22] Klose, S., Tabatabai, M.A. (1999): Urease activity of microbial biomass in soils. - Soil Biol. Biochem. 31: 205-211.

[23] Lee, K.H., Jose, S. (2003): Soil respiration, fine root production, and microbial biomass in cottonwood and loblolly pine plantations along a nitrogen fertilization gradient. - Soil Biol. Biochem. (Online 27 May).

[24] Li, X., Li, F., Singh, B., Rengelc, Z., Zhan, Z. (2007): Soil management changes organic carbon pools in alpine pastureland soils. - Soil Till. Res. 93: 186-196.

[25] Luizzao, R.C.C., Bonde, T.A., Tosswall, T. (1992): Seasonal variation of microbial biomass - the effect of clear felling in a tropical rain forest and establishment of pasture of clear felling en a rain forest and establishment of pasture in the Central Amazon. - Soil Biol. Biochem. 24: 805-813.

[26] Lynch, J.M., Panting, L.M. (1982): Effects of season, cultivation and nitrogen fertilizer on the size of the soil microbial biomass. - J. Sci. Food Agric. 23: 249-252.

[27] Manu, A., Bationo, A., Geiger, S.C. (1991): Fertility status of selected millet producing soils of West Africa with emphasis on phosphorus. - Soil Sci. 152: 315-320.

[28] Martikainen, P.J., Palojarvi, A. (1990): Evaluation of the fumigation extraction method for the determination of microbial $\mathrm{C}$ and $\mathrm{N}$ in a range of forest soils. - Soil Biol. Biochem. 22: 797-802.

[29] McCulley, R.L., Burke, I.C. (2004): Microbial community composition across the Great Plains: Landscape versus regional variability. - Soil Sci. Soc. Am. J. 68: 106-115.

[30] Mendham, D.S., Connell, A.M.O., Grove, T.S. (2002): Organic matter characteristics under native forest long term pasture, and recent conversion to Eucalyptus plantations in Western Australia: microbial biomass, soil respiration and permanganate oxidation. Aust. J. Soil Res. 40: 859-872.

[31] Parr, J.F., Papendick, R.I. (1997): Soil quality, relationship and strategies for sustainable dryland farming system. - Ann. Arid Zones 36: 181-191.

[32] Santruckova, H. (1992): Microbial biomass, activity and soil respiration in relation to secondary succession. - Pedobiologia 36: 341-350.

[33] Saratchandra, S.U., Perrot, K.W., Upsdell, M.P. (1984): Microbiological and biochemical characteristics of a range of New Zealand soils under established pasture. - Soil Biol. Biochem. 16: 177-183.

[34] Schimel, D.S., Braswell, B.H., Holland, E.A., McKeown, R., Ojima, D.S., Painter, T.T., Parton, W.J., Townsend, A.R. (1994): Climatic, edaphic, and biotic controls over storage and turnover of carbon in soils. - Global Biogeochem. Cy. 8: 279-293.

[35] Sharma, P., Rai, S.C., Sharma, R., Sharma, E. (2004): Effects of landuse change on soil microbial C, N and P in a Himalayan watershed. - Pedobiologia 48: 83-92.

[36] Singh, J.S., Raghubanshi, A.S., Singh, R.S., Srivastava, S.C. (1989): Microbial biomass acts as a source of plant nutrients in dry tropical forest and savanna. - Nature 338: 499500 .

[37] Smith, L.J., Papendick (1993): Soil organic matter dynamics and crop residue management. - In: Metting, B. (ed.), Soil Microbial Ecology. Marcel Dekker, New York.

[38] Sparling, G.P., Whale, K.W., Ramsay, A.J. (1985): Quantifying the contribution from the soil microbial biomass to the extractable P levels of fresh and air dried soils. - Aust. J. Soil Res. 23: 613-621.

[39] Srivastava, S.C., Singh, J.S. (1991): Microbial C, N and P in dry tropical forest soils. Effects of alternate land uses and nutrient flux. - Soil Biol. Biochem. 24: 117-124. 
[40] Swift, M.J., Heal, O.W., Anderson, J.M. (1979): Decomposition in Terrestrial Ecosystems. - Blackwell, Oxford.

[41] Theng, B.K.G., Tate, K.R., Sollins, P. (1989): Constituents of organic matter in temperate and tropical soils. - In: Coleman, D.C.,Oades, J.M., Uehara, G. (eds.) Dynamics of Soil Organic Matter in Tropical Ecosystems, Niftal Project, Univ. of Hawaii, pp. 1-4.

[42] Vance, E.D., Brookes, P.C., Jenkinson, D.S. (1987): Microbial biomass measurements in forest soils: the use of the chloroform fumigation incubation method for strongly acid soils. - Soil Biol. Biochem. 19: 697-702.

[43] Wardle, D.A. (1992): A comparative assessment of factors which influence microbial biomass carbon and nitrogen levels in soil. - Biol. Rev. 67: 321-358.

[44] Wardle, D.A. (1998): Controls of temporal variability of the soil microbial biomass: a global scale synthesis. - Soil Biol. Biochem. 30: 1627-1637.

[45] Williams, B.L., Sparling, G.P. (1984): Extractable N and P in relation to microbial biomass in UK acid organic soils. - Plant Soil 76: 139-148.

[46] Wright, A.L., Hons, F.M., -Matocha, J.E.Jr. (2005): Tillage impacts on microbial biomass and soil carbon and nitrogen dynamics of corn and cotton rotations. - Appl. Soil Ecol. 29: 85-92.

[47] Yadava, P.S., Devi, A.S. (2004): Impact of slash and burning on microbial biomass in semi evergreen tropical deciduous forest of Manipur, North-east India. - Korean J. Ecol. 27(4): 225-230. 